\title{
Studies on FYM and Vermi-Compost on Soil Health and Economics Profitability of Organic Fertilizer of Maize (Zea mays L.)
}

\author{
Ravindra Kumar, Uday Kumar*, Nishchal Chandrakar and Rajiv Kumar
}

${ }^{1}$ Department of Soil Science, ${ }^{2}$ Department of Agronomy, ${ }^{3}$ Department of Agricultural Biochemistry, ${ }^{4}$ Department of Extension, MGCGV, Satna, Madhya Pradesh, India

*Corresponding author

\section{Keywords}

FYM, Vermicompost, profitability, soil health and Maize

\section{Article Info}

Accepted:

15 April 2020

Available Online:

10 May 2020
Studies on response to organic fertilizer and profitability of organic fertilizer use among small-scale maize producers in Madhya Pradesh under Chitrakoot - Satna condition. Was conducted at the research and instructional farm of the Rajaula Agricultural research farm of the Faculty of Agricultural Sciences, Mahatma Gandhi Chitrakoot Gramodaya Vishwavidyalaya, Chitrakoot during kharif 2016 to find out the Effect of F.Y.M. and Vermi-compost on soil health and economics profitability of organic fertilizer of the opted treatment. The experiment was laid out in Randomized Block Design (RBD) having 09 treatments comprising of organic manures (farmyard manure and vermi-compost) each replicated three times, making a total of 27 plots. Treatments were randomly arranged in each replication. Benefit Cost ratio was highest for $T_{8}$ followed by $T_{4}$. Treatment $T_{8}$ is superior for Vermi-compost application and $\mathrm{T}_{4}$ was superior for FYM treatment.

\section{Introduction}

Maize (Zea mays L.) is one of the most important and a strategic food crop cultivated in the world. Maize was first domesticated in Mexico, from its wild species ancestor, teosinte, about 9000 years ago, but maize landraces are widely found across the continents (Gollar et al., 2016). Landraces (germplasm) evolved conventionally over the time, not only provides basic nutritional requirements as a food security but also in crop improvement programs very much depend on the availability of a wide and reliable crop genetic diversity (Verma et al., 2017).

In Madhya Pradesh state, maize is the second important crop next to paddy of food grain production. Maize crop is cultivated in Madhya Pradesh 71.75 mha area \& production $134.16 \mathrm{mt}$ and its productivity is $1886 \mathrm{~kg} / \mathrm{ha}$. Annual rainfall of M.P. in average $1300-1400 \mathrm{~mm}$. 
Coupled with 137 per cent cropping intensity (JNKVV, Jabalpur, 2015). In India, maize is grown in an area of $8.17 \mathrm{~m}$. ha with a production around $19.33 \mathrm{~m}$. tons and productivity $2414 \mathrm{~kg} / \mathrm{ha}$. It ranks next to rice, wheat, sorghum and pearl millet. It is the main staple food in hilly and sub mountain tracts of northern India and consumed all over the country as a fodder and grains. It is extensively grown in Uttar Pradesh, Rajasthan, Madhya Pradesh, Bihar and Karnataka.

Largest area of maize is in Karnataka (1.3 m. ha.) followed by Rajasthan (1.1 m. ha.) while the production is highest in Karnataka (4.4 m. tons) followed by Andhra pradesh (4 m. tons). Productivity is highest in Andhara Pradesh (5.3 t/ha) followed by Tamil Nadu (4.6 t/ha) and Karnataka (3.5 t/ha). Globally, it is cultivated on more than 160 million hectares area across 166 countries having wider diversity of soil, climate, biodiversity and management practices. Maize contributes the maximum $40 \%$ among the cereal food crops in the global food production. USA is the largest maize producer contributing nearly 35 percent to the total maize production, followed by China. Maize is the driver of the US economy, with highest productivity (>10 $\mathrm{t} / \mathrm{ha}$ ) which is double than the global average (5.3 t/ha). The productivity of maize in India is just half of the world average (DMR, 2016). The aim of the present study was to evaluate the effect of different rates of FYM and vermi-compost on the growth and yield of maize in Chitrakoot - Satna (M.P.) India.

\section{Materials and Methods}

The experiment was conducted at the research and instructional farm of Rajaula Agricultural research farm of the Faculty of Agricultural Sciences, Mahatma Gandhi Chitrakoot Gramodaya Vishwavidyalaya, Chitrakoot during kharif season of 2016. All the facilities necessary for conducting the experiment, including labour and resources, which were necessary for normal cultivation were readily available in the department. The climate of the region is semi-arid and sub-tropical having extreme winter and summer. During the winter months, the temperature drops down to as low as $1-5^{\circ} \mathrm{C}$ while in the summer the temperature reaches above $45^{\circ} \mathrm{C}$. The experiment was laid out in Randomized Block Design having 09 treatments comprising of organic manures (farmyard manure and vermi-compost) each replicated three times, making a total of 27 plots. Treatments were randomly arranged in each replication. Superstar- 9396 (Hybrid $\mathrm{F}_{1}$ ) variety of maize was selected for the experiment. This variety has been developed by Pioneer Overseas Corporation, Karnataka, cob with Grain Colour orange yellow, Ear shape conico cylindrical, Grain Texture semi flint, Disease Tolerant to turcicum leaf blight \& DM, plant type semi erect, suitable for growing in central India. Plant highs $200-220 \mathrm{~cm}$ high, Kharif Maturity (days) 90-100 and Special Features Heat tolerant. It is suitable for planting in June-July in plains.

\section{Results and Discussion}

Effect of different doses of F.Y.M. and vermi-compost on soil health

Farm Yard Manure and Vermi-compost are the organic manure and are very fruitful for improving the soil health given in Table 1. By evaluating the different doses of FYM and Vermi-compost for various grain yield and quality traits of Maize crop, it can be said that organic manure has positive impact on soil health. Among the 4 treatments of FYM, treatment-4 $\left(\mathrm{T}_{4}\right)$ was best for grain yield and other traits which indirectly indicated that this specific treatment is good for improving soil health as well as for increasing the yield and quality traits. 
Treatments, $\mathrm{T}_{8}, \mathrm{~T}_{4}, \mathrm{~T}_{7}$ and $\mathrm{T}_{3}$ were found superior for cob yield per plot $(\mathrm{kg})$ and significantly differs from other treatment but not differs from each other therefore any of them can be recommended. For Vermicompost application, treatment $\mathrm{T}_{8}$ and $\mathrm{T}_{7}$ was found significant and superior as compare to other Vermi-compost treatments therefore both of them can be recommended. For FYM application, treatment $T_{4}$ and $T_{3}$ was found significant and superior as compare to other FYM treatments therefore it can be recommended for further applications.

Farm Yard Manure and Vermi-compost are the organic manure and are very fruitful for improving the soil health. By evaluating the different doses of FYM and Vermi-compost for various grain yield and quality traits of Maize crop, it can be said that organic manure has positive impact on soil health. Among the 4 treatments of FYM, treatment-4 $\left(\mathrm{T}_{4}\right)$ was best for grain yield and other traits which indirectly indicated that this specific treatment is good for improving soil health as well as for increasing the yield and quality traits. Similarly, among the 4 treatments of Vermicompost, treatment- $8\left(\mathrm{~T}_{8}\right)$ was best for grain yield and other traits which indirectly indicated that this specific treatment is good for improving soil health as well as for increasing the yield and quality traits. Overall, treatments, $\mathrm{T}_{4}$ and $\mathrm{T}_{8}$ combination could be good for improving the soil health as well as for boosting the yield of Maize crop through organic farming.

\section{Estimation of the economics of the opted treatment}

Economics of all the treatments are given in Table 2 which showed that control treatment has lowest output as compare to other treatment. Highest output was recorded by treatment $T_{8}$ followed by $T_{4}$. Lowest input cost was taken by $T_{5}$ followed by $T_{6}$ but output of these two treatments was lower than the control treatment. Therefore $T_{5}$ and $T_{6}$ are not the suitable treatments. Highest input cost was recorded for treatments $\mathrm{T}_{4}$ followed by $\mathrm{T}_{3}$. Benefit cost ratio (B:C ratio) was also calculated and presented in Table 1 and 2. $B: C$ ratio was highest for $T_{8}$ followed by $T_{4}$. Treatment $\mathrm{T}_{8}$ is superior for Vermi-compost application and $\mathrm{T}_{4}$ was superior for FYM treatment. These two treatments were significantly differs from other treatments based on $\mathrm{CD}$ value for yield per plot. B:C ratio was also higher for these two treatments which showed that per unit input for these two treatment can return lot of output.

Table.1 Effect of different doses of FYM and Vermi-compost on soil health

\begin{tabular}{|c|c|c|c|}
\hline Sl. No. & $\begin{array}{c}\text { Treatment } \\
\text { No. }\end{array}$ & Treatment & $\begin{array}{c}\text { Grain } \\
\text { Yield }\end{array}$ \\
\hline $\mathbf{1 .}$ & $\mathrm{T}_{0}$ & $0 \%$ (control) & 2.42 \\
\hline $\mathbf{2 .}$ & $\mathrm{T}_{1}$ & $25 \%$ (F.Y.M.) & 3.23 \\
\hline $\mathbf{3 .}$ & $\mathrm{T}_{2}$ & $50 \%$ (F.Y.M.) & 3.91 \\
\hline $\mathbf{4 .}$ & $\mathrm{T}_{3}$ & $75 \%$ (F.Y.M.) & 4.10 \\
\hline $\mathbf{5 .}$ & $\mathrm{T}_{4}$ & $100 \%$ (F.Y.M.) & 4.83 \\
\hline $\mathbf{6 .}$ & $\mathrm{T}_{5}$ & $25 \%$ (Vermi-compost) & 2.84 \\
\hline $\mathbf{7 .}$ & $\mathrm{T}_{6}$ & $50 \%$ (Vermi-compost) & 3.70 \\
\hline $\mathbf{8 .}$ & $\mathrm{T}_{7}$ & $75 \%$ (Vermi-compost) & 4.13 \\
\hline $\mathbf{9 .}$ & $\mathrm{T}_{8}$ & $100 \%$ (Vermi-compost) & 4.98 \\
\hline
\end{tabular}


Table.2 Economics of the opted treatments for Maize crop

\begin{tabular}{|c|c|c|c|c|c|c|}
\hline Treatment & $\begin{array}{c}\text { Yield } \\
(\mathbf{q} / \mathbf{h a})\end{array}$ & $\begin{array}{c}\text { Yield } \\
\text { (kg/ha) }\end{array}$ & $\begin{array}{c}\text { Rate of } \\
\text { maize seeds }\end{array}$ & $\begin{array}{c}\text { Total output } \\
\text { (Rs.) }\end{array}$ & $\begin{array}{c}\text { Input cost } \\
\text { (Rs.) }\end{array}$ & B:C ratio \\
\hline $\mathbf{T}_{\mathbf{0}}$ & 16.14 & 16140 & $120.00 / \mathrm{kg}$ & 1936800 & 8340 & 232.23 \\
\hline $\mathbf{T}_{\mathbf{1}}$ & 21.54 & 21540 & $120.00 / \mathrm{kg}$ & 2584800 & 8236 & 313.84 \\
\hline $\mathbf{T}_{\mathbf{2}}$ & 26.07 & 26070 & $120.00 / \mathrm{kg}$ & 3128400 & 8452 & 370.14 \\
\hline $\mathbf{T}_{\mathbf{3}}$ & 27.34 & 27340 & $120.00 / \mathrm{kg}$ & 3280800 & 8668 & 378.50 \\
\hline $\mathbf{T}_{\mathbf{4}}$ & 32.2 & 32200 & $120.00 / \mathrm{kg}$ & 3864000 & 8884 & 434.94 \\
\hline $\mathbf{T}_{\mathbf{5}}$ & 18.94 & 18940 & $120.00 / \mathrm{kg}$ & 2272800 & 8127 & 279.66 \\
\hline $\mathbf{T}_{\mathbf{6}}$ & 24.67 & 24670 & $120.00 / \mathrm{kg}$ & 2960400 & 8236 & 359.45 \\
\hline $\mathbf{T}_{\mathbf{7}}$ & 27.54 & 27540 & $120.00 / \mathrm{kg}$ & 3304800 & 8344 & 396.07 \\
\hline $\mathbf{T}_{\mathbf{8}}$ & 33.2 & 33200 & $120.00 / \mathrm{kg}$ & 3984000 & 8451 & 471.42 \\
\hline
\end{tabular}

Therefore it can be concluded that Treatment $\mathrm{T}_{8}$ and $\mathrm{T}_{4}$ were overall best performing treatments for maize crop. Economics of all the treatments showed that control treatment has lowest output as compare to other treatment. Highest output was recorded by treatment $T_{8}$ followed by $T_{4}$. Lowest input cost was taken by $\mathrm{T}_{5}$ followed by $\mathrm{T}_{6}$ but output of these two treatments was lower than the control treatment (Golada et al., 2013). Benefit Cost ratio was highest for $\mathrm{T}_{8}$ followed by $\mathrm{T}_{4}$. Treatment $\mathrm{T}_{8}$ is superior for Vermicompost application and $\mathrm{T}_{4}$ was superior for FYM treatment. These two treatments were significantly differs from other treatments based on $\mathrm{CD}$ value for yield per plot. B: $\mathrm{C}$ ratio was also higher for these two treatments which showed that per unit input for these two treatments can return lot of output (Arvadiya $e t$ al., 2017).

\section{References}

Arvadiya, L. K., Raj, V. C., Patel, T. U. and
Arvadiya, M. K. (2017). Effect of F.Y.M. and Vermi-compost on yield and associated in analysis of maize (Zea mays L.). Indian Journal of Agronomy, 57(2): 62-67.

DMR (2016). "Maize Biology: An Introduction". Directorate of Maize Research, ICAR, New Delhi.

Golada, S. L., Sharma, G. L. and Jain, H. K. (2013). Effect of organic manures and inorganic fertilizers on growth and yield in maize under sub humid condition in Rajasthan, India. African Journal of Agricultural Research, 8(12): 1100-1107.

Gollar, R. G. and Patil, V. C. (2016). Effect of organic manures and inorganic fertilizers on yield and quality of maize. Journal of Plant Science, 13(1): 1-6.

Verma, A. and Tomar, G. S. (2017). Effect of F.Y.M. and Vermi-compost different levels on grain yield and quality of maize (Zea may saccharata Sturt.) Journal of Agriculture Issues, 18(1-2): 31-33.

\section{How to cite this article:}

Ravindra Kumar, Uday Kumar, Nishchal Chandrakar and Rajiv Kumar. 2020. Studies on FYM and Vermi-Compost on Soil Health and Economics Profitability of Organic Fertilizer of Maize (Zea mays L.). Int.J.Curr.Microbiol.App.Sci. 9(05): 2038-2041. doi: https://doi.org/10.20546/ijcmas.2020.905.232 